\title{
The Angst of Youth in Post-Industrial Japan: A Narrative Self-Help Approach
}
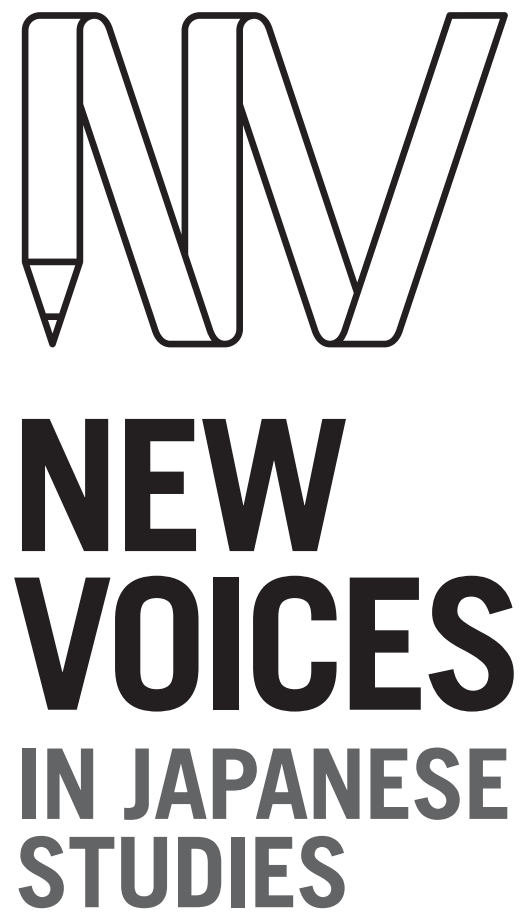

\section{RIE KIDO}

The University Of Adelaide

\section{ABSTRACT}

This paper explores the experience of angst (ikizurasa) among youth in longterm unemployment in post-industrial Japan, and proposes a model for supporting them. Currently, the dominant model for unemployment support consists of activation policies, which assume that users can identify their problems and clarify their needs in job seeking. However, for youth in situations of long-term unemployment, the effectiveness of these policies is limited. This paper argues that indirect support which focuses on (re)constructing human relationships through sharing narratives is a more effective way to help such youth mitigate their angst. In-depth interviews with two participants in a Self-Help Group for youth affected by long-term unemployment, as well as participant observations of the group, reveal how a narrative approach allowed participants to build new senses of self founded in realities shared by others. The analysis shows how these developments were crucial to helping the participants to find employment that suited their situations and needs.

\section{KEYWORDS}

angst; hikikomori; ikizurasa; isolation; labour force; narrative; post-industrial society; precarity; self-help; unemployment; youth

\section{JAPANFOUNDATION 8 \\ BRINGING JAPAN TO YOU \\ To link to this article: \\ http://dx.doi.org/10.21159/nvjs.08.05}

ISSN 2205-3166

New Voices in Japanese Studies is an interdisciplinary, peer-reviewed journal showcasing the work of emerging scholars from Australia and New Zealand with research interests in Japan.

All articles can be downloaded free at $\underline{\text { newvoices.org.au }}$

(c) The Japan Foundation, Sydney and Rie Kido, 2016

\section{(c) $(1)$}

This work is licensed under a Creative Commons Attribution-NonCommercialNoDerivatives 4.0 International License. 


\section{INTRODUCTION: IKIZURASA, OR INDEFINABLE ANGST AMONG YOUTH}

'Ikizurasa' (生きづらさ; lit., 'pain of living') is an expression that refers to a form of anxiety experienced by youth in post-industrial Japanese society, and is often associated with a sense of disconnectedness and self-blaming or suicidal tendencies (Tsukino 2007; Allison 2013). For example, Karin Amamiya, an activist and writer, regards herself as "always having had ikizurasa and suicidal tendencies” (ずっと生きづらく、自殺願望を持っていた) and states that this suicidal tendency was at its strongest when she held an insecure job (Amamiya 2007, 12). She explains:

\begin{abstract}
The jobs I did were dull jobs that could be done by anyone, and I fell into a vicious cycle where the more I was engaged in the monotonous work, the more worthless I felt [...]. Unstable job status intensifies an unstable mental condition, and the feeling of not being needed by society easily leads to a lack of self-worth. ${ }^{1}$
\end{abstract}

(Amamiya 2007, 12)

Ikizurasa refers to feelings of solitude, anxiety, low self-esteem, hopelessness and/or anger. Causes of ikizurasa are variously suggested to be unemployment, mental illness, family problems and/or being a school misfit. Amamiya holds that "many young people constantly experience a vague feeling of ikizurasa without knowing the reasons for it” (自分でも理由が分からずつねに漠然とし た生きづらさを抱えている人が多い) (Amamiya 2007, 13).

Amamiya and Kayano (2008) argue that this condition has two aspects: socioeconomic angst, and personal-mental angst (8-9). Socio-economic angst comes from degrading work conditions, lack of equality due to a widening socioeconomic gap (Satō 2000; Tachibanaki 2006) and the pressures of poverty (Yuasa 2008; Abe 2011), while personal-mental angst comes from a lack of self-worth and/or difficulty in relating to others. In reality, however, socioeconomic and personal-mental angst are intertwined in complex experiences, which makes it hard for people to narrate their experiences of ikizurasa in an understandable form. Yuasa and Nihei (2007) divide youth unemployment discourse in Japan in the 2000s into two categories: 1) “youth bashing” (若者 バッシング), in which youth were reproached for their lack of motivation; and 2) critiques which emphasised that youth are motivated but lack employment opportunities (330). Yuasa and Nihei argue that neither discourse can satisfactorily explain the feelings of youth who either "do not want to work" or who "want to work but can neither work nor move on" $(2007,330)$. This lack of an interpretive frame exacerbates the isolation of these youths and can generate a sense of ikizurasa. Yukiko Hijikata (2010) describes ikizurasa as a "nested agony" (入れ子式の苦しさ), which refers to "plural agonies, invisible in daily situations, ... hard to understand for both oneself and others, all of which amplify one’s difficulties” (複数の苦しさで構成され、日常では見えにくい部分が 存在しており……見えないために自他共に理解しがたく、そのことが、さらに苦し 
さを増大させている状態) (262). In short, the problem is that marginalisation from society due to lack of-or menial-employment in turn leads to a sense of alienation, in which victims find it difficult to understand their experiences or to share them with others. This article focuses on marginalised Japanese youth and explores: 1) how they experience ikizurasa in real life situations, and 2) how best to support them. In order to explore these issues, this article introduces a Self-Help Group in Osaka (hereafter, 'the SHG'), in which about ten to twenty marginalised youth meet once a month to discuss their feelings of angst. The SHG is run by a separate non-profit organisation (NPO) called 'Generative Garden'. The SHG is not funded by government because it does not align with government aims for youth support, which focus on finding jobs through career education, job matching and/or training (Tsutsui et al. 2014, 31). This allows the SHG to flexibly and practically respond to the ongoing daily problems of the participants.

I was involved in the establishment of the group in 2011, and have participated in the meetings as coordinator since then. This research project was developed through this experience and was informed by the action research cycle (Elliott 1991, 70; McNiff 2013, 56-61). Based on analysis of data collected through indepth interviews with participants and participant observation in the SHG, I will argue that: 1) young people who suffer from this kind of angst or ikizurasa have difficulty identifying their problems and the causes of their problems; and 2) underlying their angst is a deep sense of disconnectedness from others and from society. This article shows how, in the SHG, people became more capable of articulating their needs and constructing their sense of self by sharing their narratives with others. It further shows how that was made possible, not so much by directly attempting to fix participants' 'problems', but indirectly through allowing them to build new kinds of relationships with others based on a sharing of narratives. I suggest that the establishment of a new kind of relationality for them was the key to redressing participants' sense of angst, and that the SHG provided a social setting which made this possible. This article thus argues that the narrative approach (White and Epston 1990; Anderson and Goolishian 1992; Noguchi 2002) is significant in supporting marginalised youth who experience alienation in post-industrial societies, with people in Japan as a case in point.

\section{BACKGROUND TO YOUTH ANGST AND LIMITATIONS OF EXISTING SUPPORT FRAMEWORKS}

Ikizurasa which is exacerbated by economic pressure and often leads to alienation at work is a characteristic of post-industrial societies, where marginalisation of workers is common (Beck 1992; Furlong and Cartmel 2006; Berardi 2009; Standing 2011). For example, Franco 'Bifo' Berardi (2009) discusses "alienation of the soul", which can be understood as a similar phenomenon to ikizurasa (Allison 2013). He argues that in late capitalism, a "cognitariat", a compound of 'cognitive' and 'proletariat', emerges as a response to the advent of a newly flexible labour force. A key characteristic of the cognitariat, he continues, is that their cognitive dimensions, including 
desires, emotions and understandings of the meaning of life, have been affected by work conditions to such an extent that they have been influenced at the level of their "soul", with the consequence that their lives in their entirety become subject to relations determined by capital (Berardi 2009, 23). These alienating conditions aggravate states of panic or depression (Berardi 2009, 22-23).

Japan entered its post-industrial phase around 1994, when the service industry started to employ more people than the manufacturing industry (Oguma 2014, 17). In 1995, the Japan Business Federation (日本経営者団体連盟), ${ }^{2}$ an employers' organisation, published a report titled 'Japanese-style Management for a New Era' [新時代の日本的経営] ${ }^{3}$, advocating flexible employment practices which made it easier to place employees on casual or short-term fixed contracts, moving away from a more traditional model of permanent employment contracts in return for employees' company loyalty. This report proposed dividing Japanese employees into three categories: 1) core regular workers who develop firm-specific skills based on secure tenure; 2 ) highly skilled specialists employed for a short term but rewarded with high wages; and 3) low-skilled workers employed temporarily with low wages. Employers were encouraged to use these different types of employment (Japan Business Federation 1995). Around the same period, OECD (Organization for Economic Co-operation and Development) labour market statistics show a substantial increase in job insecurity among young people. The youth unemployment rate, which had been $4-5 \%$ during the 1980s and early 1990s-notably low compared with western countries-rose to around $10 \%$ in the 2000 s, reaching closer to the levels of Australia and the USA (see Chart 1). Correspondingly, the nonregular employment rate increased significantly among young people from

Chart 1: Youth Unemployment Rate, Ages 15-24 (OECD 2014)

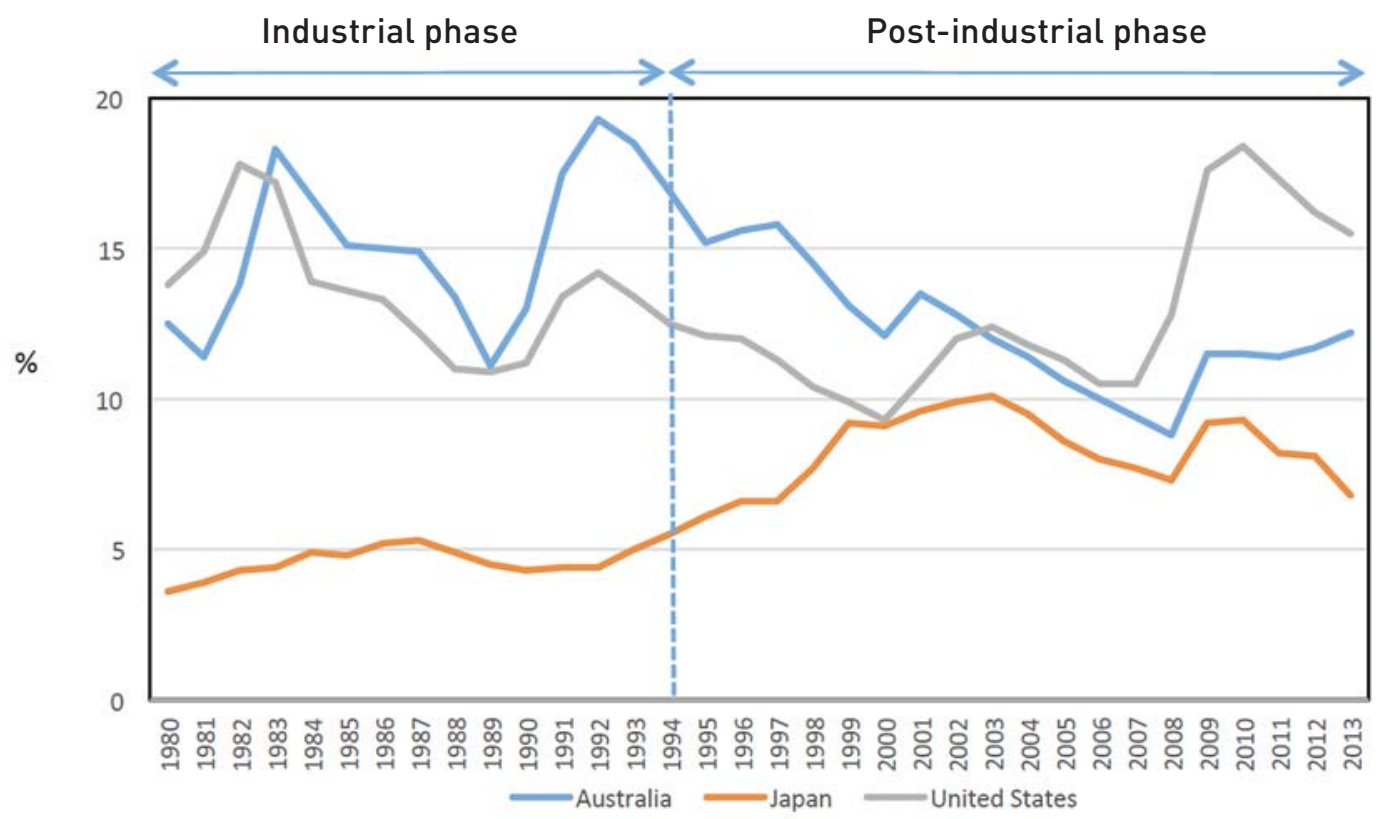

2 This organisation has since changed its name to the Japan Federation of Economic Organizations (経済団体

3 The English title of this report is the author's translation. The report is listed under the Japanese title in the 
the mid-1990s (Chart 2). In parallel, the word ikizurasa started to gain public recognition from the mid-1990s (Chart 3). According to the Cabinet Office, in $201254 \%$ of young people in their 20s felt that "they have experienced hardship in their social or daily life" (Cabinet Office 2012).

Chart 2: Non-Regular Employee Rate (Gender, Age), (MIAC 2014)

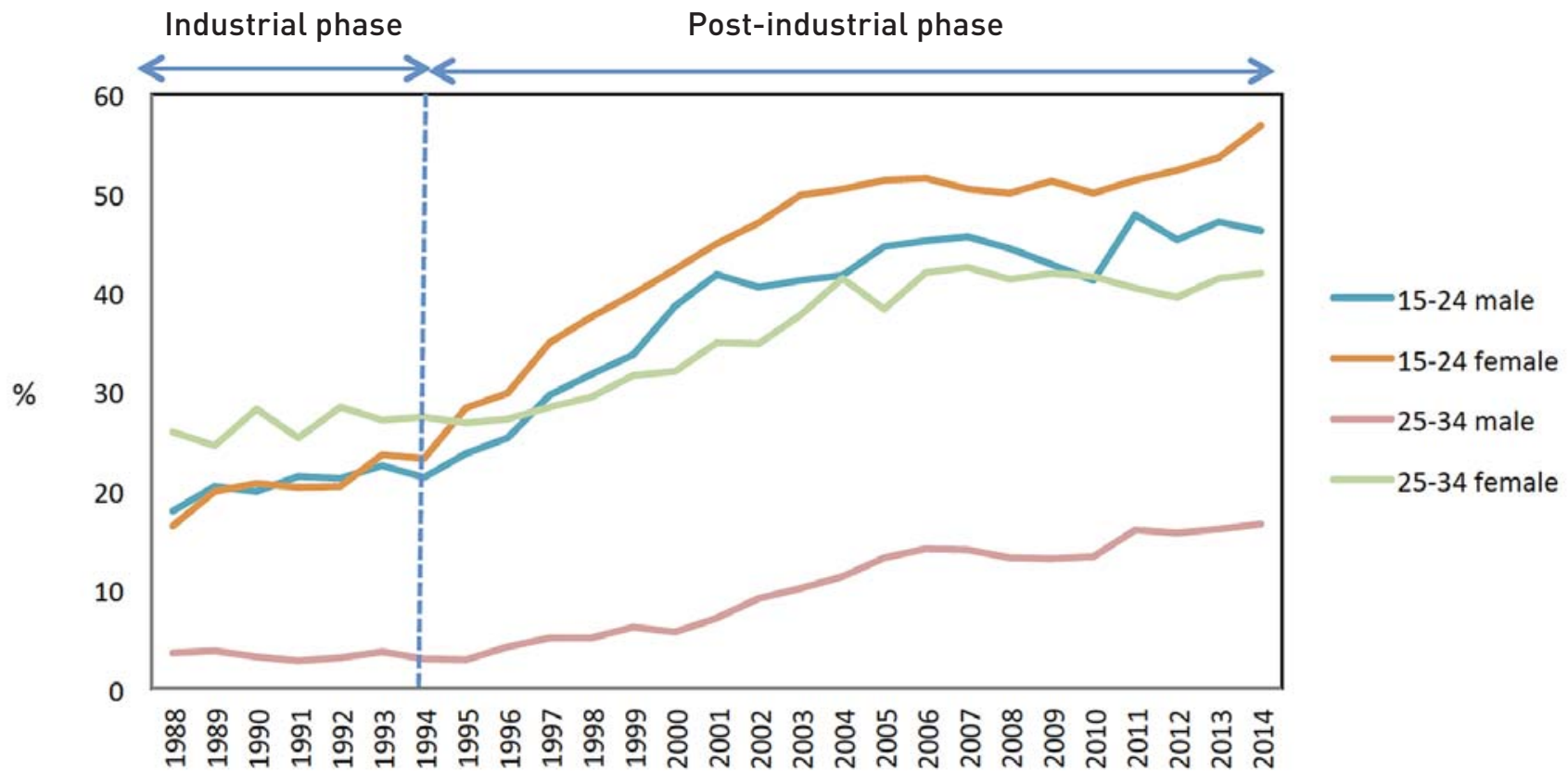

Chart 3: Total Number of Hits for 'Ikizurasa' by Keyword Search in Kikuzō 2 [聞蔵 II, Asahi Newspaper Article Search Engine] and the National Diet Library (NDL) Search

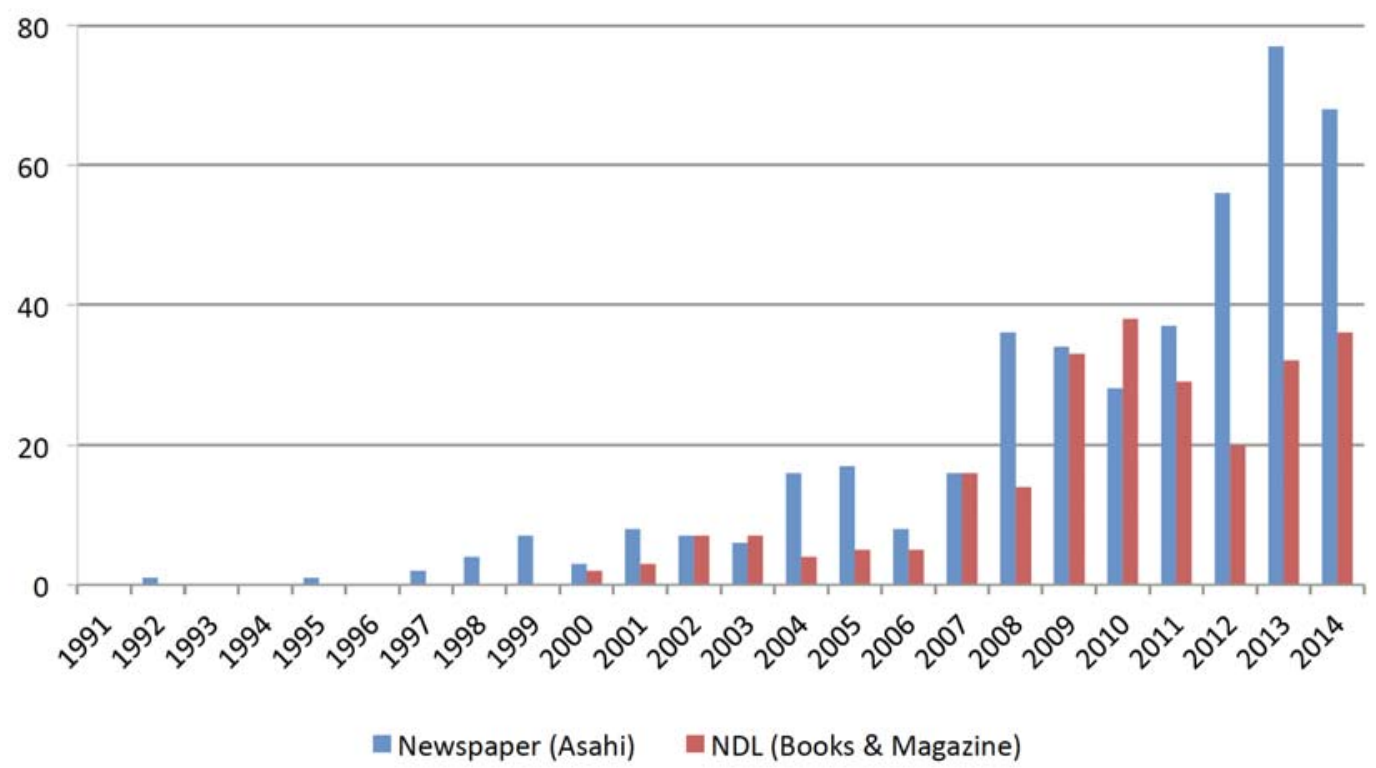

Since the early 2000s, the Japanese government has been adopting activation policies designed to bring "more people into the effective labour force, to counteract the potentially negative effects of unemployment and related benefits on work incentives" by stimulating individuals' motivation and attitudes towards employment (Duell et al. 2010; OECD 2013, 132). In 2003, 
the Plan of Challenge and Independence for Youth (若者自立挑戦プラン) was developed by a combination of the Ministry of Education, Culture, Sports, Science and Technology (MEXT), the Ministry of Health, Labour and Welfare (MHLW), the Ministry of Economy, Trade and Industry (METI) and the Cabinet Office. Based on this policy, a series of youth-related projects was developed, such as Job Cafe (ジョブカフェ), a community-based comprehensive employment support centre for youth, and the Japanese Dual System (日本型デ ユアルシステム), which offered combined programs of education at vocational schools and job skills training in organisations. In 2006, the Communitybased Youth Support Station (地域若者サポートステーション) was established as a base for youth support networks run by local governments.

Despite the investment in these initiatives, it is doubtful how effective activation frameworks can be in addressing youth anxieties, because activation policies primarily presuppose the participation of individuals who can clarify their own needs both to supporters and to themselves. Weil et al. (2005) have investigated activation policies in Europe and point out that, in the case of people whose sense of self is unstable because of prior hardships, putting pressure on them to work will have a limited effect since they often lack the social and psychological resources to make the necessary steps for a sustainable future. This can be seen in the following example:

Take Bob for example ... in and out of care homes, a mother that couldn't cope, a father he did not get on with, an unsuccessful school career, low self-esteem, and a life of emotional turmoil. [...] he had a problem engaging with 'life out there'-outside the project [i.e., job support]. In this situation, coaching Bob into the hard realities of labor market participation and the threatening loss of benefit would not give rise to any sustainable solution to the social exclusion that characterized his life.

(Weil et al. 2005, 143).

In Japan, too, it has been pointed out that there are unemployed people who have problems which cannot be resolved by job-support programs. Kei Kudō is the head of 'Raising-up Network' (育て上げネット), an NPO that aims to provide job support for youth. He argues that for unemployed youth to ask for support, it is necessary for them to first "recognise what to consult on" ( 相談したいことが明らかになっている), and to develop “trust in the person they consult with” (相談したい他者が信頼できる) (Kudō and Nishida 2014, 118). However, according to a survey by Kudō, more than $70 \%$ of unemployed youth who visited an employment support institution "[do] not even know how to manage unemployment” (無業である際に「どうしたらいいのか」すらわ からなかった), and this rate reached above $90 \%$ in the case of those who had been unemployed for more than three years (Kudō and Nishida 2014, 118-19). Considering the above issues, it is clear that support for unemployed youth, who experience angst and can neither clarify their needs nor trust others, should occur at a different level and employ a different approach. What, then, could be an approach, and at what level might it work best? 


\section{NARRATIVE APPROACHES}

In the following I explore the possibility of a narrative approach as a means for personal reinvention for marginalised youth, and to help them to cope with and redress the problem of angst. Weil et al. (2005) recognise that in these cases, "the capacity to construct and re-construct our identities and new narratives of self ... becomes an essential skill", and insist that "support for the development of such capacity [must] be made integral to notions of 'activation'” (8).

In light of this, I focus on a self-help practice which is based on a narrative approach. From a social constructionist perspective, a narrative approach understands that people interpret their experience as a narrated reality that is constructed through discursive interaction with others (White and Epston 1990; Anderson and Goolishian 1992). This narrative approach originated in family therapy, and has spread to many other fields including sociology, anthropology and management (Noguchi 2009). Existing clinical practices based on this approach include: 1) Narrative Therapy, 2) Self-Help Groups, 3) Open Dialogue, and 4) Tōjisha Kenkyū (当事者研究), or 'Self-Directed Study'.

Narrative Therapy is a method of family therapy where a problem is externalised by an individual and redefined as a "problem-saturated" narrative, which is gradually "re-authored" by the individual into a more positive and fulfilling story (White and Epston 1990, 16). This is achieved by communication between the client and the therapist, where the client is regarded as powerful enough to construct new voices and the therapist respectfully listens and engages with them, thus overcoming the traditional paternalism of a doctor-patient dyad (Anderson and Goolishian 1992).

Self-Help Groups are groups that facilitate mutual assistance among people who experience similar problems (Kubo 2004). Self-Help Groups are characterised by several features: 1) face-to-face interaction; 2) spontaneous organisation; 3) personal participation; 4) members' engagement in some action; 5) focus on "powerlessness"; and 6) connection and identification with others as a source of ego-reinforcement (Katz and Bender 1976, 9-11; Katz 1981, 136). This method has been applied in various fields including treatment of addiction and chronic disease (Gartner et al. 1971).

Open Dialogue is a psychiatric treatment which was developed in Finnish Western Lapland and has proved to be effective in reducing schizophrenia (Seikkula et al. 2000). In Open Dialogue, patients, the people in their social networks and crisis intervention teams hold open treatment meetings together, from first contact to the end of the intervention (Seikkula 2002). The aim is "to create a joint space for a new language, in which things can start to have different meanings" (Seikkula 2002, 266).

Töjisha Kenky $\bar{u}^{4}$ is a self-help method that emerged in a psychiatric care community, Urakawa Beteru no Ie (浦河べてるの家; 'Urakawa Bethel House'), in Hokkaido, Japan. In Tōjisha Kenkyū, people get together and 'study' 
themselves in communication with others who may have similar problemspredominantly schizophrenia (Urakawa Beteru no Ie 2005; Kumagaya 2015). It is reported that this method is effective in developing a sense of connectedness based on shared dialogue, as well as an understanding of one's own problems (Ayaya and Kumagaya 2008). It has been applied to various kinds of chronic difficulty, such as addiction or autism (Ayaya and Kumagaya 2008; Kamioka and Ōshima 2010).

The SHG, the object of this discussion, can be seen as a Self-Help Group because: 1) it meets all of the above qualities of a Self-Help Group; 2) it is not a medical treatment and thus cannot be classified as Narrative Therapy or Open Dialogue; and 3) while the terms Self-Help Group and Töisha Kenkyū both refer to general methods and can be used more generally in a variety of situations, it seems that Self-Help Groups are used more often than Töjisha Kenkyū.

\section{OUTLINE OF FIELDWORK}

\subsection{The Field: The SHG}

In the SHG, youth who define themselves as experiencing ikizurasa get together and share their experiences through conversation. The objective is neither for participants to get a job nor to recover from illness, but to collaborate with others in a way that is more focused on self-exploration and examination than everyday communication. Since it began in 2011, the SHG has met mostly once a month in Osaka. Each meeting has approximately ten to twenty participants and takes about four hours. Most participants are in their twenties or thirties, and have experienced one of the following: futōkō (不登校; school non-attendance) ; $^{5}$ unemployment/insecure employment; hikikomori (ひきこもり; isolating oneself in one’s house) ${ }^{6}$; addiction; mental illness; and/or family-related problems.

The meetings take different forms. The most frequently used style is the 'Individual Report', where a self-nominated 'Reporter of the Day' prepares a written text about a specific personal difficulty, to which other participants give feedback by referring to their own experiences. Another popular style is Free Talk, in which participants discuss freely 'The Theme of The Day', focusing on issues such as 'My Fear of Communication'.

The SHG meetings are run with two mentors present: a coordinator and a moderator. Since the program began, I have participated as coordinator in 48 of the 51 meetings, mainly to facilitate the sharing of narratives by interpreting or providing social context for them. The moderator of the SHG 
also established the youth support NPO called 'Generative Garden' in 2006. 'Generative Garden', which runs the SHG, is an 'ibasho' (居場所; a place to 'be'), or a “space with a receptive atmosphere” (受容的な空間) (Abiru 2012, 37), particularly for youths. Ibasho usually means an open (and opened) space where a person is free (but not forced) to participate in any activities and can relate with others in a safe and secure social atmosphere without coercion. Thus, 'Generative Garden' is an ibasho mainly for unemployed youth where they can be without pressure to (find) work. The SHG meetings are open to the public and people can take part as members or otherwise. The moderator organises meetings and also facilitates the generation of narratives.

Although the coordinator and moderator play key roles in the SHG, it is emphasised in all meetings that they are there primarily as participants rather than supporters or specialists.

This follows the 'equal', or less paternalistic, relationship between the client and the therapist that characterises the narrative approach. By contrast, in a traditional therapeutic situation, the relationship is limited to a clearly defined patient-therapist relationship because: 1 ) it is the client who suffers from a problem; and 2) experts are paid for their expertise to take responsibility according to industry standards as skilled practitioners. The mentors in the SHG are neither psychological nor psychiatric specialists, but the mentor has 20 years of experience in supporting futōkō and/or hikikomori children and youth, and the coordinator has 10 years of research experience in this area. Should something go wrong, participants have access to qualified psychological/psychiatric support personnel outside the SHG.

The 'equal' relationships that are a defining characteristic of a Self-Help Group are important because they help participants to feel more comfortable in relating with others, and to address problems through their own initiative, rather than under specialists' directions. Indeed, in a post-industrial neoliberal environment of precarious employment and increased stress, both carer/ supporter/mentor and client are exposed to angst, albeit not at the same level (Beck 1992). Thus, in the SHG meetings, given that the mentors are not paid, the mentors are nearly on the same level as the participants and do not have the same responsibilities or training as a therapist.

\subsection{Methodology and Data Collection}

This research focuses on interpreting the narratives of group participants in a context where the researcher is actively involved in coordinating group meetings. Therefore, it adopts a qualitative methodology (Glaser and Strauss 1967; Flick 2014). It shares the practical attitude of Action Research which is oriented by "change and improvement" (McNiff 2013, 54); in this case, of youth support initiatives currently available in Japan. Action Research basically operates on a continuous cycle of plan-action-reflection, with the researcher(s) involved throughout (Lewin 1946; Elliot 1991; McNiff 2013). 
For this study, the data collected were: 1) participant observations; 2) semistructured narrative interviews with participants; and 3) written text made available by participants, including their 'Individual Reports' and other related written materials. Participant observation of the SHG meetings was conducted from January to October 2015, and ten meetings were observed. For all but one session, held in January during fieldwork in Japan, Skype was used to observe the meetings from Australia. Seventeen in-depth interviews were conducted in January 2015 in Hyogo and Osaka. The interviews were held in cafés, a meeting room in 'Generative Garden', and a university classroom. Each session took approximately 1.5-3 hours. The interviewees were young adults aged in their twenties and thirties who had participated in the SHG at least three times. The interviewees included 3 females and 14 males, and they were each asked to narrate their stories of ikizurasa, their work experience, and how they felt about the SHG, including (if relevant) how their lives had changed due to their participation. The interviews were audiorecorded and transcribed later. Texts that the interviewees had written were used to supplement their narratives.

In the following sections, I discuss two such narratives as case studies, which have been selected for the following reasons: 1) the participants' experiences of angst are typical of those of other interviewees and thus represent a commonly expressed narrative on these topics; and 2) the narrators had been participants of the SHG for a long time, so their commitment to the group had made them particularly articulate and their narratives were more detailed than those of others. $^{7}$

\section{NARRATIVES OF IKIZURASA}

\subsection{Case 1: Mai Sasaki (Female, Aged 26)}

Mai Sasaki [pseud.; b. 1988] started futōkō (school non-attendance) when she was nine years old. Being a good student, she did not have a clear reason for futōkō, but when going to school and being told to get good scores and to act as a model student, she could not help feeling as if she was being "told to become a machine” (機械になれと言われているみたい) (Sasaki 2015a). ${ }^{8}$ Mai comes from a typical middle-class family, consisting of herself, a housewife mother, a salaryman father and a younger sister. Mai's parents did not directly blame or scold her for not attending school, but she keenly felt their strong hope that she would return to school or work. She spent her teenage years mostly isolating herself in her house. When she was 20 , she felt she had no choice but to work and found a job at a post office, and then at a shopping centre as a cleaner. However, she could not bear to act as though she were a robot, and she quit both within two weeks. Blaming herself as "unproductive and not worthy of living” (生産性がなく生きているのが申し訳ない), Mai increasingly found it difficult to enter public spaces and started cutting her wrists. She felt tranquil only when she read books and wrote essays.

7 Some details of the stories have been modified to protect privacy but with due care to not to change the import of the narrative or to interfere with analysis.

8 Hereafter in this section, Mai's words are from Sasaki 2015a unless otherwise indicated. Details of this and other participant data are listed in the Appendix. 
Looking for new human relationships, she searched on the internet and found 'Generative Garden'. She liked the mood of the place, where "No one was keen to rescue me” (誰もがんばって助けようとしない). Recovering her cheer and energy, she attended the SHG meetings and participated in exploring the meaning of her sense of ikizurasa. As one of the earliest and keenest members of the meetings, she wrote 'Individual Reports' several times. The themes of her reports include 'Pain and Anger' and 'Writing Myself Out'.

Asked how the SHG had helped her to change, Mai answered, "I stopped seeing my ikizurasa as negative, and although living is painful I started to feel okay with it” (生きづらい自分を否定的に捉えなくなった。生きづらいんだけじ、い いかって). She continued:

In the early days [of participation], I thought that I was to blame. I felt that it was my fault I was feeling ikizurasa, and that I had to fix it. I had lived in a world where only I and the people around me existed. But ... as I read books and listened to other people's projects, my perception changed. My view started to shift from being 'it's all my fault' to 'there is something that can be shared in my experience'. In such a problematic system, there must be many other people who feel the same pain. ${ }^{9}$

After three years of participation, Mai was offered a job writing articles by a newspaper editor who visited the SHG meetings. She was very happy because it was her dream job, but it was also a new challenge for her. As she worked on the articles, she realised her writing topics had been limited to her personal experiences and perceptions, which might interest those who knew her but not those who did not. In light of this realisation, she started to think, "I am a part of this society ..., even though I sometimes cannot fit into it. If so, I may have to write something related to society” (うまく馴染むことができない側面が あるにしても、私もこの社会の一員。……れなら、社会とつながりのあるものを書 いてみたい) (Sasaki 2015b).

\subsection{Case 2: Kōsuke Noguchi (Male, Aged 27)}

Kōsuke Noguchi [pseud.; b. 1987] was one of the oldest members of the SHG. He was raised in a family which consisted of a salaryman father, a housewife mother and a little sister.

When he was young, Kōsuke did not receive affection from his family. His father was a serious worker, but drank at home and was abusive toward Kōsuke. He started to hate his father and felt lonely. At school, too, Kōsuke did not meet people he could think of as "real friends" (親友) (Noguchi 2015a)..$^{10}$ When he was in junior high school, he started to fear that he had an unpleasant body odour. His mental condition worsened, causing Kōsuke quit school when he was 16. After that, he was obsessed by the idea of what he called "investigating the truth of the universe” (宇宙の真理を探究する) (Noguchi 2012). 
At the age of 18, Kōsuke could not help thinking about being violent toward his father and himself. Trying frantically to find somebody to stop him, Kōsuke called a twenty-four-hour suicide prevention hotline and was introduced to 'Generative Garden'. This encounter changed his life. As he related himself to other members of 'Generative Garden', Kōsuke's violent impulses subsided. He also started to participate in the SHG meetings.

Kōsuke wrote 'Individual Reports' on 'The Relationship between Father and Me' and 'My Mental Illness'. After completing his first report, he experienced a sense of fulfilment and contentment. He wrote:

I felt a warm affection for my own words, which came from the bottom of my heart. I felt that my words gained energy when others reacted positively toward them. [...] Rather than shut them within myself, I felt I wanted to let them travel around others through communication. [...] It also led me to listen to others and make comments on others' projects. ${ }^{11}$

(Noguchi 2015b)

In one report, he analysed his passion towards "the truth of the universe" as admiration for something eternal and absolute, and as "a substitute for the intimate affection which I was denied” (愛されなかった代わり) (Noguchi 2012).

Kōsuke's life changed a lot during his participation in 'Generative Garden' and the SHG. First and foremost, in 2013 he started to work on a regular basis. He worked in disability care for 7 hours a day, 5-6 days a week, and this was his first experience of working regularly. He felt the job fit him well, because he "cannot live in a world where people are always competing to become managers” (課長になるとかいつも競争している世界ではやっていけない), while for him the field of disability care includes "basic human relationships" (普 通の人間と人間の関係). In addition, he left his parents' house and started to live with another male member of the SHG. With distance, his attitude to his father changed: "I could never work for my family without ever complaining like him. I just want to express my gratitude and say to him 'well done”" (彼の ように家族のために……不平も言わず働くことは決してできない。お疲れ様という 感謝の気持ちを示すほかない) (Noguchi 2012).

It seems that the guided self-help experience helped Kōsuke to achieve a positive frame of mind, but he emphasised that this was not an intended consequence. Kōsuke remarked, "My original aims never work out as planned" (最初から ねらいを定めるとうまくいかない). Although he did not expect much from the SHG when he started, he “continued because it was fun”(おもしろかったから 続けてきただけ).

\section{ANALYSIS}

\subsection{What is Happening in the SHG Meetings?}

This section presents an analysis of the changes I observed in Mai and 
Kōsuke through the SHG meetings, based on my participant observations as coordinator. These two cases point to the complex issues faced by youth who are experiencing ikizurasa and prolonged unemployment, and the need for less conventional methods of support. Instead of seeking to activate in the participant a robust and rational outlook, I argue that these cases show how greater self-acceptance through positive feedback from others can be more helpful to the individual in fostering a desire to seek employment and taking interest in other life objectives.

In the early stage, most SHG participants expressed that they felt emotional pain and a sense of isolation. They expressed feeling alienated from a society that seemed to be antagonistic toward them and they felt they could not be understood by others. Painful memories of being rejected by family members or failure in school aggravated feelings of anxiety and impulsive anger. While these emotions were tangible, in the early stage of the meetings participants could not identify their emotional needs or the real causes of their situations. Thus they would interrogate themselves: "Why am I so bad?" (Mai) or "What is the truth of the universe?" (Kōsuke).

In the latter stages, however, this attitude began to shift. Through discussions in the SHG meetings, participants had the opportunity to be listened to with care and to listen to others' frank expressions of their experiences without normative value-judgements. Kōsuke started to "feel an affection for" his narrative as other participants positively accepted it. As she listened to others' stories, Mai realised she was not the only one to suffer from a sense of ikizurasa. These kinds of experiences are common among the SHG participants.

The chance to relate positively with others gave participants the necessary encouragement to redefine negative past experiences and to treat them as subjects of investigation. Mai thus replaced her sense of not fitting in with the notion that there is something structural in her personal trouble. Kōsuke came to regard his violent father as a businessman who worked to support his family and was able to stop hating him. Such redefinition potentially helps participants to (re)generate a new sense of self. Mai redefined herself as "being a part of this society". Kōsuke started to grasp a sense of being accepted by others, which allowed him to recognise the damage caused by his abusive father instead of thinking that he himself was to blame. In this way, they created new self-narratives that they could be proud of, and which were founded in the narratives shared by others around them.

Participation in the SHG meetings also brought about greater clarity in the minds of the participants about their own needs. Vague thoughts such as 'I cannot become like my father' (Kōsuke) or 'I am scared of work' (Mai) became more realistic questions like, 'What would be a suitable mode of work for me?' Thus, employment might become a practical and sustainable option once an identification of personal needs, based on a clearer understanding of one's self, is established. Disability care in Kōsuke's case and writing newspaper articles in Mai's case suggest that they were able to apply themselves when they found appropriate jobs at the right time and at a reasonable pace for them. 


\subsection{Indirect Aim-setting}

A crucial question that emerges from these narrative reconstructions is, what are the conditions that foster such generation of positive narratives? Here it is argued that 'indirect aim-setting' and 'enhancement of dialogue' are key factors. Indirect aim-setting is represented in the fact that the SHG meetings aim to offer participants the opportunity to deeply explore their own experiences in structured dialogues, but do not specifically help them to find a job. Thus, even if the participants finally do find a job, this can be interpreted as a by-product of a clearer understanding of self and trustful relationships with others. This also means that those cases which do not result in finding jobs would not be regarded here as unsuccessful.

Indirect aim-setting is particularly important because it enables all group members, including mentors, to participate. It stimulates dialogue and helps facilitate problem solving. If the direct aim is 'to get a job', there is a clear boundary between the supporters and the supported, and the participants are easily regarded as recipients of support services. This sets up the definition of success as getting a job, and a gap emerges between those who are successful and those who are not. But when the target is for participants 'to address their own problems', the participants are inspired to become active investigators of their lives. The two participants shown in the case studies naturally related themselves to the job world through their experiences in the SHG meetings. Although this was not always the case, there are many other cases where participants reported similar experiences.

Although it is crucial that mentors facilitate communication in meetings, it is also important that other participants can provide help as peers and feel equally invested in the group. It was observed that this process almost inadvertently brought back participants' pride, regenerated a sense of capacity, and rekindled excitement in living with a sense of autonomy in their own lives. These qualities are seriously lacking in the conditions typically established in support services.

Indirect aim-setting is also an important characteristic of an ibasho or place to 'be' (Araya 2012, 234), of which 'Generative Garden' is one. In the context of youth support, an ibasho is structured to avoid setting short-term goals, such as going (back) to school or work, and allowing people to focus on resting in an environment free from pressure. This attitude of 'offering no explicitly productive activities' can, in appropriate circumstances, help people develop self-esteem, through which they can begin to think of ways to relate to society (NPO Tōkyō Shūre 2000; Tsutsui et al. 2014).

\subsection{Enhancement of Dialogue}

A narrative produces positive impact when it is supported by people who listen to it carefully and respond to it positively. When it is reinforced through another's genuine acknowledgement, the narrator feels greater confidence in its validity. In order for this to happen, the SHG protocol emphasises that: 1) 
comments should start with 'I' as much as possible (e.g., 'I do not think so' instead of 'It is not true'); 2) value judgements should be minimised as much as possible in responses (e.g., 'You really had a hard time when you didn't go to school' instead of 'School non-attendance is bad'); 3) in responding to a narrative, the respondent then shares their story (e.g., 'That sometimes happens to me, too. In my case ... '). While the mentors participate in this process, they also guide the conversations to ensure that they remain within these parameters.

Seikkula (2002) argues that while speech or a story is produced by an individual, dialogue is "a process", a primary outcome of which is to create relationality (266). Thus, in enhancing dialogue, relationships are focused on more than what is narrated or whose narrative it is. The self which is (re) constructed in this process can be seen as a "relational being", as proposed by Gergen (2009). Challenging the concept of the individual as an entirely free and rational entity who takes all responsibility for their actions, Gergen understands human beings as products of multiple relationships, and argues that knowledge or recovery that is brought about by social practices such as education or therapy, and is not an individual achievement but rather a fruit of effective co-action (Gergen 2009, 240-309). The SHG facilitates selfexploration for young people by creating a forum for hearing and accepting each other's narratives, allowing a kind of relationality to be achieved. Thus, it seems that the enhancement of dialogue fosters more positive self-images in young people who experience angst in their work and living conditions.

\section{CONCLUSION}

In this article I have examined the angst of youth (ikizurasa) in post-industrial Japan. I have focused on a specific Self-Help Group through participant observation to identify the characteristics of a practice that can, within limits, support such youth. From interviews and other material collected through the group's meetings, I found that angst was experienced as the disintegration of a person's mental and physical health, and their relationships with family members and society. I have argued that the main problem of youth who experience such angst is their lack of a robust sense of self and an inability to clarify their needs, which seriously hampers them in utilising existing governmental support programs. As an alternative, this article has shown the effectiveness of a Self-Help Group. This effectiveness is based on: 1) indirect aim-setting, in which participants do not aim at finding a job but at sharing narratives, so as to create the conditions for them to engage subjectively in the group meetings at their own pace and often with pride and a sense of fun; and 2) enhanced dialogue, involving the creation of relationships where participants volunteer their personal experiences, which are carefully heard and receptively responded to.

Unfortunately, in the institutional setting of Japan today, government youth support programs are established in a more paternalistic relationship, where the aims are to directly find clients jobs and the existing framework of activation policies presupposes fully self-reliant individuals. A new framework 
of relation-oriented practices is needed to support unemployed youth, where the aims are to help the individual come to accept themselves and better clarify their needs. It is being gradually realised by local governments that having more human relationships can be effective for career development (Tsutsui et al. 2014, 204).

The observations of particular experiences of youth angst in this article are not unique to Japanese society and are typical to post-industrial societies where there are conditions of casualised work and unemployment. Similarly, my methodology is shared by other Self-Help Group practitioners in these societies. If we are to address the issue of youth angst properly, I contend that it is necessary for us to redefine unemployment itself: to move from seeing it as a temporary situation and to recognise instead that it is a chronic and structural reality that affects a substantial section of society. As indicated in the discussion of the two case studies, a narrative approach can be used to help youth whose precarious socio-economic conditions aggravate their experience of angst, by giving them the opportunity to find support through open, trusting and focused discussions with others.

To focus on narratives and individual identities does not, however, mean ignoring political responsibility for the socio-economic conditions that youths are exposed to. It is vital to recognise that not only a change in personal narratives but also a change in labour conditions is pivotal to minimising youth marginalisation in post-industrial societies. Self-Help Groups and ibasho complement existing therapeutic programs and government activation programs. In order to address and ameliorate the "alienation of the soul" (Berardi 2009, 23) that is typical to late-capitalist societies, it is a pressing priority to deliver support that can be effective for the well-being and career development of different kinds of young people.

\section{APPENDIX: LIST OF INTERVIEWS AND ESSAYS FROM THE FIELD}

Noguchi, K. [pseud.]. 2012. Individual Report. In SHG Meeting Reports 1.

2015b. Support documentation for interview. Addressed to the researcher.

2015a. Interview by the researcher. Digital recording in Japanese. January 12.

Sasaki, M. [pseud.]. 2015a. Interview by the researcher. Digital recording in Japanese. January 11.

2015b. Individual Report. In SHG Meeting Reports 3.

\section{GLOSSARY}

hikikomori (ひきこもり)

a person who isolates themselves inside their house and does not participate in society, or the state of doing so; becomes a problem by the late twenties 
lit., a place to 'be'; an open (and opened) space where a person is free to participate

in any activities and can relate with others in a safe and secure social atmosphere

without coercion

\section{ikizurasa (生きづらさ)}

lit., 'pain of living'); a form of anxiety or angst experienced by youth in post-industrial Japanese society, often associated with a sense of disconnectedness and self-blaming or suicidal tendencies

futōkō (不登校)

school non-attendance for reasons other than illness or economic problems

\section{Tōjisha Kenkyū (当事者研究)}

'Self-Directed Study'; a self-help method that emerged in a psychiatric care community in Japan where people get together and 'study' themselves in communication with others who may have similar problems

\section{REFERENCES}

Abe, A. [阿部 彩]. 2011. Jakusha no ibasho ga nai shakai: Hinkon, kakusa to shakaiteki hōsetsu[弱者の居場所がない社会: 貧困・格差と社会的包捸]. Tokyo:Kōdansha Gendai Shinsho [講談社現代新書].

Abiru, K. [阿比留 久美]. 2012. “Ibasho” no hihanteki kentō” [「居場所]の批判的検討]. In Wakamono no ibasho to sanka: Yūsu wāku ga kizuku arata na shakai [若 者の居場所と参加一ユースワークが築く新たな社会], edited by H. Tanaka [田中 治彦] and K. Hagiwara [萩原 健次郎], 35-51. Tokyo: Tōyōkan Shuppansha [東洋観出版社].

Allison, A. 2013. Precarious Japan. Durham and London: Duke University Press. http://dx.doi.org/10.1215/9780822377245

Amamiya, K. [雨宮 処燷]. 2007. Ikisasero!: Nanmin-ka suru wakamono tachi [生きさ せろ!：難民化する若者たち]. Tokyo: Ōta Shuppan [太田出版].

Amamiya, K. [雨宮 処凛] and T. Kayano [萱野 稔人]. 2008. Ikizurasa ni tsuite: Hinkon, aidentiti, nashonarizumu [生きづらさについて:貧困、アイデンティテ イ、ナショナリズム]. Tokyo: Kōbunsha Shinsho [光文社新書].

Anderson, H. and H. Goolishian. 1992. "The Client is the Expert: A Not-knowing Approach to Therapy." In Therapy as Social Construction, edited by S. McNamee and K. Gergen, 25-39. London: Sage.

Araya, S. [新谷 周平]. 2012. “Ibasho o umidasu 'shakai' no kōchiku” [居場所を生み 出寸「社会」の構築]. In Wakamono no ibasho to sanka: Yūsu wāku ga kizuku arata na shakai [若者の居場所と参加一ユースワークが築く新たな社会], edited by H. Tanaka [田中 治彦] and K. Hagiwara [萩原 健次郎], 231-47. Tokyo: Tōyōkan Shuppansha [東洋観出版社]. 
Ayaya, S. [綾屋 紗月] and S. Kumagaya [熊谷 晋一郎]. 2008. Hattatsu shōgai tōjisha kenkyū: Yukkuri teinei ni tsunagaritai [発達障害当事者研究：ゆっくりてい㸚 いにつながりたい]. Tokyo: Igaku Shoin [医学書院].

Beck, U. 1992. Risk Society: Towards a New Modernity. Translated by M. Ritter. London: Sage.

Berardi, F. B. 2009. The Soul at Work: From Alienation to Autonomy. Translated by F. Cadel and G. Mecchia. Cambridge, MA: Semiotext(e).

Cabinet Office. 2012. Wakamono no kangaekata ni tsuite no chōsa [若者の考え方 についての調査]. Tokyo. Accessed 14 February, 2016. http://www8.cao.go.jp/ youth/kenkyu/thinking/h24/pdf_index.html.

Duell, N., D. Grubb, S. Singh and P. Tergeist. 2010. "Activation Policies in Japan." In OECD Social, Employment and Migration Working Papers, 113. London: OECD Publishing.

Elliot, J. 1991. Action Research for Educational Change. Buckingham: Open University Press.

Flick, U. 2014. An Introduction to Qualitative Research. 5th edition. London: Sage.

Furlong, A. and F. Cartmel. 2006. Young People and Social Change. New York: McGraw-Hill.

Gartner, A., M. C. Kohler and F. Riessman. 1971. Children Teach Children: Learning by Teaching. New York: Harper and Row.

Gergen, K. 2009. Relational Being: Beyond Self and Community. New York: Oxford University Press.

Glaser, B. and A. Strauss. 1967. The Discovery of Grounded Theory: Strategies for Qualitative Research. Chicago: Aldine Publishing Company.

Hijikata, Y. [土方 由紀子]. 2010. “Kodomo no ikizurasa to wa nani ka: Risuku shakai $n i$ okeru futōkō” [子どもの生きづらさとは何か：リスク社会における不登校]. Nara joshi daigaku shakaigaku ronshü [奈良女子大学社会学論集] 17: 259-76.

Japan Business Federation [日本経営者団体連盟]. 1995. “Shin-jidai no 'nihon-teki keiei': chōsen subeki hōkō to sono gutai-saku” [新時代の「日本的経営」： 挑戦 すべき方向とその具体策]. Tokyo.

Kamioka, H. [上岡 陽江] and E. Ōshima [大嶋 栄子]. 2010. Sonogo no fujiyū: 'Arashi' no ato o ikiru hito-tachi [その後の不自由: 「嵐」のあとを生きる人たち]. Tokyo: Igaku Shoin [医学書院].

Katz, A. H. 1981. "Self-Help and Mutual Aid: Emerging Social Movement?". Annual Review of Sociology 7 (1): 129-55. http://dx.doi.org/10.1146/annurev. so.07.080181.001021

Katz, A. H. and E. I. Bender. 1976. The Strength in Us: Self-help Groups in the Modern World. New York: New Viewpoints. 
Kubo, H. [久保 紘章]. 2004. Serufu herupu gurūpu: Tōjisha e no manazashi [セルフへ ルプ・グループ： 当事者へのまなざし]. Tokyo: Aikawa Shobō [相川書房].

Kudō, K. [工藤 啓] and R. Nishida [西田 亮介]. 2014. Mugyō shakai: Hataraku koto ga dekinai wakamono tachi no mirai [無業社会：働くことができない若者たち の未来]. Tokyo: Asahi Shinsho [朝日新書].

Kumagaya, S. 2015. “Tojisha Kenkyu of Autism Spectrum Disorders.” Advanced Robotics 29 (1): 25-34. http://dx.doi.org/10.1080/01691864.2014.967723

Lewin, K. 1946. “Action Research and Minority Problems.” Journal of Social Issues 2 (4): 34-46. http://dx.doi.org/10.1111/j.1540-4560.1946.tb02295.x

MEXT (Ministry of Education, Culture, Sports, Science and Technology). 2015. Heisei 26 nendo jidō seito no mondai-kōdō tō seito-shidō-jō no shomondai ni kansuru chōsa [平成26年度 览童生徒の問題行動等生徒指導上の 諸問題に関する調査]. Tokyo. Accessed 19 October, 2015. http://www.mext. go.jp/b_menu/houdou/27/09/1362012.htm.

MIAC (Ministry of International Affairs and Communications). 2014. Labour Force Survey [労働力調査]. Tokyo. Accessed 19 October, 2015. http://www.stat. go.jp/data/roudou/longtime/03roudou.htm.

McNiff, A. 2013. Action Research: Principles and Practice. 3rd edition. New York: Routledge.

Noguchi, Y. [野口 裕二]. 2002. Monogatari to shite no kea: naratibu apurōchi no sekai e [物語としてのケア:ナラティブ・アプローチの世界へ]. Tokyo: Igaku Shoin [医学書院].

2009. Narativu apurōchi [ナラティヴ・アプローチ]. Tokyo: Keisō Shobō [勁草 書房].

NPO Tōkyō Shūre [NPO法人東京シューレ]. 2000. Furīsukūru to wa nani ka: kodomo ga tsukuru, kodomo to tsukuru [フリースクールとは何か：子どもが創る・子ど もと創る]. Tokyo: Kyōiku Shiryō Shuppankai [教育史料出版会].

OECD (Organization for Economic Co-operation and Development). 2013. Employment Outlook. OECD Publishing.

2014. "Labour Market Statistics.” In Main Economic Indicators (database). Accessed 19 October, 2015. http://dx.doi.org/10.1787/data-00046-en

Oguma, E. [小熊 英二]. 2014. “Sōsetsu” [総説]. In Heisei-shi [平成史], edited by E. Oguma, 13-97. Tokyo: Kawade Shobō [河出書房].

Saitō, T. [斎藤 環]. 1998. Shakaiteki hikikomori: Owaranai shishunki [社会的ひきこも り：終わらない思春期]. Tokyo: PHP Shinsho [PHP新書].

Satō, T. [佐藤 俊樹]. 2000. Fubyōdō shakai Nippon [不平等社会日本]. Tokyo: Chūkō Shinsho [中公新書]. 
Seikkula, J. 2002. "Open Dialogues with Good and Poor Outcomes for Psychotic Crises: Examples from Families with Violence." Journal of Marital and Family Therapy 28 (3): 263-74. http://dx.doi.org/10.1111/j.1752-0606.2002. tb01183.x

Seikkula, J., B. Alakare and J. Aaltonen. 2000. "A Two-year Follow-up on Open Dialogue Treatment in First Episode Psychosis: Need for Hospitalization and Neuroleptic Medication Decreases." Social and Clinical Psychiatry 10: $20-29$.

Standing, G. 2011. The Precariat: The New Dangerous Class. London \& New York: Bloomsbury.

Tachibanaki, T. [橘木 俊昭]. 2006. Kakusa shakai: Nani ga mondai na no ka [格差社 会: 何が問題なのか]. Tokyo: Iwanami Shinsho [岩波新書].

Tsukino, K. [月乃 光司]. 2007. Byōki dayo! Zen’in shūgō [病気だョ! 全員集合]. Tokyo: Shinkigensha [新紀元社].

Tsutsui, M. [筒井 美紀], J. Sakurai [櫻井 純理] and Y. Honda [本田 由紀]. 2014. Shūrō shien o toinaosu: Jichitai to chiiki no torikumi [ 就労支援を問い直す：自治体 と地域の取り組み]. Tokyo: Keisō Shobō [勁草書房].

Urakawa Beteru no Ie. [浦河べてるの家]. 2005. Beteru no ie no 'tōjisha kenkyū' [ベて るの家の「当事者研究]]. Tokyo: Igaku Shoin [医学書院].

Weil, S., D. Wildemeersch and T. Jansen. 2005. Unemployed Youth and Social Exclusion in Europe. Surrey: Ashgate.

White, M. and D. Epston. 1990. Narrative Means to Therapeutic Ends. New York: W. W. Norton \& Company.

Yuasa, M. [湯浅 誠]. 2008. Han hinkon: “Suberidai shakai” kara no dasshutsu [反貧 困：「寸べり台社会」からの脱出]. Tokyo: Iwanami Shinsho [岩波新書].

Yuasa, M. [湯浅 誠] and Nihei, N. [仁平 典弘]. 2007. “Jakunen hōmuresu: 'Iyoku no hinkon' ga teikisuru toi” [若年ホームレス:「意欲の貧困」が提起する問い]. In Wakamono no rōdō to seikatsu sekai: Karera wa donna genjitsu o ikiteiru no ka [若者の労働と生活世界：彼らはどんな現実を生きているのか], edited by Y. Honda [本田 由紀], 329-62. Tokyo: Ōtsuki Shoten [大月書店]. 